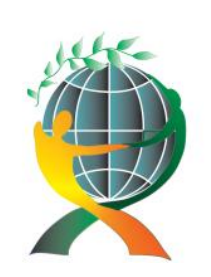

\author{
(online) $=$ ISSN $2285-3642$ \\ ISSN-L = 2285 - 3642 \\ Journal of Economic Development, Environment and People \\ Volume 3, Issue 3, 2014 \\ URL: http://jedep.spiruharet.ro \\ e-mail: office jedep@spiruharet.ro
}

\title{
Virtual Teams and E-leadership in the Context of Competitive Environment - Literature Review
}

\author{
Ioana Manole ${ }^{1}$ \\ ${ }^{1}$ Spiru Haret University /ASE Bucharest
}

\begin{abstract}
Globalization, accelerated movement of goods, technology and information transformed society in recent decades in unprecedented ways. In the context of a generation that focuses on continuous innovation and creativity at the highest levels, ability to lead and motivate people represents one of the best qualities of a manager, regardless of the activity. Unprecedented growth of competition, the need to reduce costs by automating continuous processes and create a competitive advantage in a market where the supply of goods and services is similar are forcing companies to put increasing emphasis on human resources. As part of creating competitive advantage, organizations relocate and create virtual teams in order to reduce costs, but keep the quality of the products or service, but they self-expose to risks if the virtual teams are not managed efficiently.

The present article aims to explore new directions for leadership competencies in virtual context, reviewing the basic team characteristics from the traditional environment through new requirements based on virtual experience particularities.
\end{abstract}

Keywords: virtual team, e-leadership, leading virtual teams, complex society, leadership competencies, virtual context

JEL Codes: O3, M5, L1

\section{Introduction}

As a response to a challenging business environment, organizations wanted to benefit from technology development and create virtual team, instead of investing money on building offices in numerous locations across the world [Chinowsky P. S., Rojas E. M., 2003]. These changes created opportunities for organization to overcome the barrier of hiring local employees, and to benefit from the experience and knowledge of experts across countries or continents [Hunsaker P. L., HunsakerJ. S, 2008]. However, this involves some risks and challenges the team are exposed to, as the context is changed and the role of the leader in virtual settings must sustain the performance of the business. 


\author{
(online) = ISSN $2285-3642$ \\ ISSN-L = 2285 - 3642 \\ Journal of Economic Development, Environment and People \\ Volume 3, Issue 3, 2014 \\ URL: $\underline{\text { http://jedep.spiruharet.ro }}$ \\ e-mail: office jedep@spiruharet.ro
}

\title{
2. Literature review
}

\subsection{Virtual teams}

Contributions A Virtual Team or remote team [Nevogt, D., 2013] is a group of people with complementary competencies [Chinowsky et al., 2003] who work across time, space and organizational boundaries with links strengthened by webs of communication technology [Lipnack, J., 2000]. The main features of virtual teams are: working with online tools (via telephone, e-mails, video conferences), across time zones, no face to face interactions, different organizational contexts [Bal \& Teo 2000; Kayworth\&Leidner 2002].

As research studies have demonstrated, the number of virtual teams is on the rise, with almost a quarter of a billion people already working online globally and increasing [Bergiel et al., 2008]. If in the former stage, virtual teams were created for simply project-based, they migrated to being permanent structures consisting of several team members located across the globe with their direct line managers located in different countries [Picolli, Powel \& Ives 2004; Bal \&Teo 2000; Purvanova \& Bono 2009].

Table 1. The main advantages and disadvantages of virtual teams

\begin{tabular}{|c|c|}
\hline Advantages & Disadvantages \\
\hline $\begin{array}{l}\text { Reducing relocation time and costs, reduced } \\
\text { travel costs }\end{array}$ & Lack of physical interaction \\
\hline $\begin{array}{l}\text { Reducing development times and time-to- } \\
\text { market }\end{array}$ & $\begin{array}{l}\text { Challenges are more related to the distance between team } \\
\text { members than to their cultural or language differences }\end{array}$ \\
\hline $\begin{array}{l}\text { Provide a vehicle for global collaboration and } \\
\text { coordination of R\&D-related activities }\end{array}$ & $\begin{array}{l}\text { Challenges of determining the appropriate task technology } \\
\text { fit }\end{array}$ \\
\hline $\begin{array}{l}\text { Able to tap selectively into centres of excellence, } \\
\text { using the best talent regardless of location }\end{array}$ & $\begin{array}{l}\text { Cultural and functional diversity in virtual teams lead to } \\
\text { differences in the members' thought processes }\end{array}$ \\
\hline $\begin{array}{l}\text { Teams can be organised (whether or not } \\
\text { members are in proximity to each other) }\end{array}$ & Developing trust among the members is challenging \\
\hline Greater degree of freedom to individuals & Challenges and obstacles like technophobia \\
\hline $\begin{array}{l}\text { Provide organizations with unprecedented level } \\
\text { of flexibility and responsiveness }\end{array}$ & $\begin{array}{l}\text { Variety of practices (e.g. cultural and work process } \\
\text { diversity) and employee mobility can negatively impact } \\
\text { performance }\end{array}$ \\
\hline $\begin{array}{l}\text { Organizations seeking to leverage scarce } \\
\text { resources across geographic and other } \\
\text { boundaries }\end{array}$ & Team members need special training and encouragement \\
\hline Sharing knowledge, experiences & $\begin{array}{l}\text { Everything to be reinforced in a much more structured, } \\
\text { formal process }\end{array}$ \\
\hline
\end{tabular}

Source: Ebrahim, Ahmed \&Taha (2009)

Taking into account the advantages of creating a virtual team, it is necessary to respond to the challenges that appear and find solutions to better integrate the persons to a virtual team, as they may 


\author{
(online) $=$ ISSN $2285-3642$ \\ ISSN-L = $2285-3642$ \\ Journal of Economic Development, Environment and People \\ Volume 3, Issue 3, 2014 \\ URL: $\underline{\text { http://jedep.spiruharet.ro }}$ \\ e-mail: office jedep@spiruharet.ro
}

never actually met face to face. Actually, virtual teams are often built for non-routine tasks [Corso, Martini, Pellegrini, Massa,Testa, 2006], based on knowledge sharing [Cramton, 2001], through online media. This trend toward remote work groups has necessitated a detailed analyses into the role, responsibilities and competencies of e-leaders [Mogale L., Sutherland M., 2010].

\title{
2.2. Virtual leadership
}

As identifying the positive and negative aspects of the virtual teams, a closer look should be taken on leaders who need to manage the team, and the features of the new type of leader being born, e-leader[ Mogale L., Sutherland M., 2010].

Leadership is an intricate construct that can be described and measured in multiple ways [Mogale L., Sutherland M., 2010]. The complexity of this concept, which involves interaction between three elements: the leader, his followers and the context or situation in which it is exercised [Bennis w., Nanus B., 1985] transposes in the virtual environment, with some particularities. Organizational scientists have begun to talk about "e-leadership" to refer to leaders who conduct many of the processes of leadership largely though electronic channels [Zaccaro, Bader, 2003].

Authors Avolio, Kahai and Dodge (2000)define e-leadership as -"a social influence process mediated by AIT (advanced information technology) to produce a change in attitudes, feelings, thinking, behaviour, and/or performance with individuals, groups, and/or organizations". As online media is a developing sector in the economy, leaders need to integrate this form of communication "in every hierarchical level in an organization" [Avolio, Kahai, Dodge, 2000], involving both one-to-one as well as one-to-many interactions over electronic media [Das Gupta P., 2011].

The main challenge for a virtual leader is creating the team, and an appropriate environment for members to know each other and build trust relationships, in order to approach the common goals. At a first view, the limitation of channels of interaction may be considered a boundary, but key online channels like social media may create the same bound as in a traditional team and give member a point to start a strong relationship based on trust and knowledge sharing. This represents one of the key factors an eleader should include in his strategy of coordinating virtual teams.

As the scope of creating virtual teams is engaging the most appropriate specialists into the projects, solving geographical or temporal separations, managing the team for maximal performance is one problem more that needs to be fixed. In order to achieve maximal performance in virtual teams, e-leaders need to set goals and vision, clearly explain the role of every member and encourage them to share knowledge and experience, and organise habitual meeting, video conferences to create a common ground and keep the idea of membership, even if members are located in different geographical space. Also, encouraging incentives and provide recognitions for good performance keep the members motivated to achieve great results[Abbasnejad, Moud, 2012], because, regardless the place where it is located and the type of work a person does, employees will always be motivated by material or immaterial rewards. 


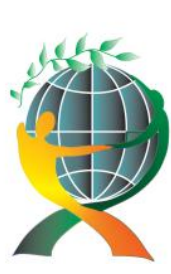

\author{
(online) $=$ ISSN $2285-3642$ \\ ISSN-L = 2285 - 3642 \\ Journal of Economic Development, Environment and People \\ Volume 3, Issue 3, 2014
}

URL: http://jedep.spiruharet.ro

e-mail: office jedep@spiruharet.ro

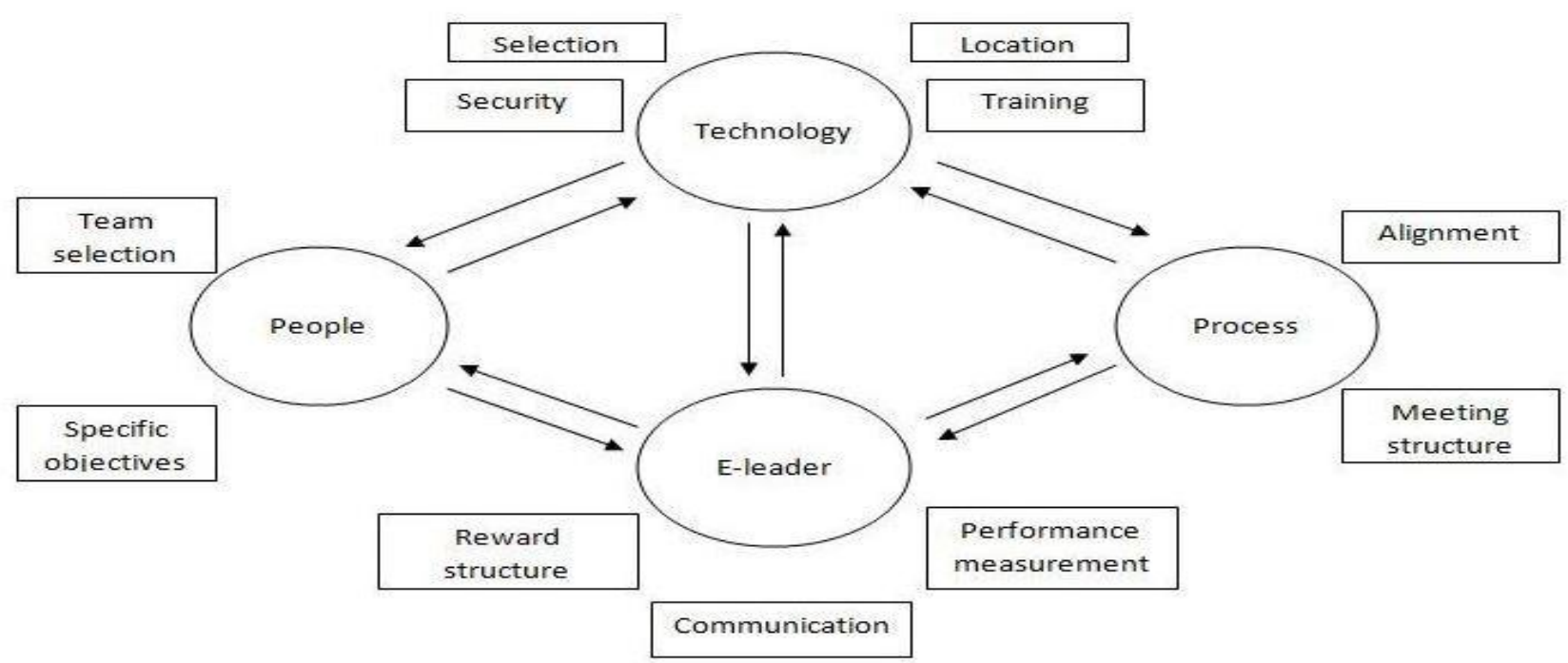

Fig. 1. Valid model for virtual team working

Source: Personal remake after Bal and Gundry(1999)

\title{
2.3. Future research
}

If the direction is set to virtual teams and competitive advantages are taking companies in areas never reached before, future research in implementing virtual teams in small and medium businesses and university environment would be essential for developing a new path for these concepts. The development and application of this new model of work in different areas of activity should be studied in order to provide the features of virtual teams managed in specific situations..

\section{Conclusions}

Virtual teams will not fully replace traditional teams in the future, but represent an alternative to reducing costs for big companies that need to maintain a competitive advantage and offer same products and services as the competitors, with the same quality and a smaller price. Investment in technology always represents a productive mode to interpolate money into business, with positive return of investment, if tools and human resources are perfect integrated in a new business system, through e-leaders. Virtual teams represent new and exciting work form with many aspects which may represent subject for future research, as it is a developing phenomenon in organizations. The opportunities and challenges provided by remote users must consist in internal opportunities also for technology companies, to develop new efficient ways to communicate and make virtual interactions as easy as Google is nowadays.

\section{References}

[1] Bennis W., Nanus B., Leaders:The Strategies for Taking Charge, Ed. Harper\&Row, 1985, p.32;

[2] Lipnack, J.,Virtual Teams: People Working Across Boundaries with Technology. John Wiley \& Sons, 2000, p. 352. 


\author{
(online) $=$ ISSN $2285-3642$ \\ ISSN-L = 2285 - 3642 \\ Journal of Economic Development, Environment and People \\ Volume 3, Issue 3, 2014 \\ URL: http://jedep.spiruharet.ro \\ e-mail: office jedep@spiruharet.ro
}

ISBN 0471388254;

[3] Zaccaro, S. J., \& Bader, P. (2003). E-Leadership and the Challenges of Leading E-Teams:Minimizing the Bad and Maximizing the Good. Organizational Dynamics, 31(4), 377-387;

[4] Abbasnejad B., Moud H. I., Leadership functions and challenges in virtual teams - A Review Paper, Department of Civil Engineering, Division of Construction Management, Chalmers University ofTechnology, S-412 96 Gothenburg, Sweden, 2012;

[5] Avolio, B. J., \&Kahai, S. (2003). Adding the -ell to e-leadership: How it may impact your leadership. Organizational Dynamics, 31(4);

[6] Bal, J., Teo P.K., Implementing virtual teamworking. Part 1: a literature review of best practice.Logistics Information Management, 2001, 13: 346 - 352;

[7] Jay Bal, John Gundry, (1999) "Virtual teaming in the automotive supply chain", Team Performance Management: An International Journal, Vol. 5 Iss: 6, pp.174 - 193;

[8] Chinowsky P. S., Rojas E. M., Virtual teams: Guide to successful implementation. J. Manage. Eng. 2003, 19(3): 98106;

[9] DasGupta P., Literature Review: e-Leadership, Emerging Leadership Journeys, Regent University, 2011 Vol. 4 Iss. 1 , pp. 1- 36;

[10] Hunsaker P. L., Hunsaker J. S., Virtual teams: A leader's guide,Team Perf. Man, 2008, 14(1-2): 86-101;

[11] MyriamKaroui, Ali Gürkan, AurélieDudezert, Virtual Team Collaboration: A Review of Literature and Perspectives, Proceedings of the Sixteenth Americas Conference on Information Systems, Lima, Peru; August 12-15, 2010;

[12] Mogale L., Sutherland M, Managing virtual teams in multinational companies, South African Journal of Labour Relations: Vol 34 No 2 2010;

[13] Nevogt, D., No Excuses: The Definitive Guide to Building a Remote Team: Table of Contents. Hubstaff. Retrieved, 21 June 2013; 